\title{
Die uitspraak '... en saam laat sit in die hemel' (Ef 2:6) as voorbeeld van 'n eskatologiese hoogtepunt in die brief aan die Efesiërs
}

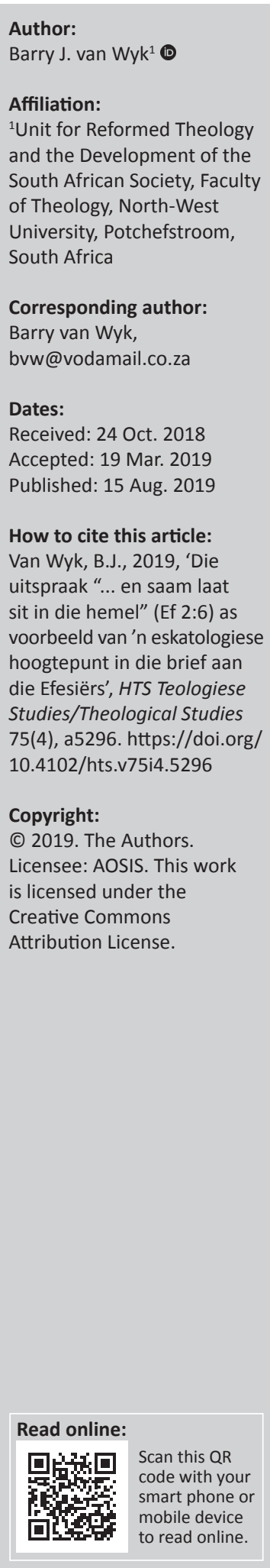

The sentence 'to rule with him in the heavenly world' (Eph 2:6) as example of an eschatological highlight in the letter to the Ephesians: The viewpoint in this article is that the above-mentioned statement in the letter to the Ephesians can be seen as an eschatological sentence of extraordinary value. In view of different eschatological viewpoints from the past, it can be stated that this sentence is an example of eschatology not only for the future, but also for the present. It is understandable that there is a close link between eschatology and mission. The meaning of theosis (deification), a concept from the Eastern churches' theological debate, underlines the need for a present eschatological consciousness that has significance for the future of church and faith. Believers can in this way escape from the destructive lust that is in the world, and may become partakers of the divine nature.

Keywords: Eschatology; Christian eschatology; Theosis; Missional; Realised future.

\section{Inleidend}

Dié uitspraak in die Efesiërbrief is nou gekoppel aan Christus Jesus soos dit in die brief deur die skrywer verwoord word. Die oortuiging bestaan dat geloof wat nie op die toekoms gebaseer is nie, en net op die verlede en die hede gebaseer is, onbruikbaar is en waarskynlik nie veel meer is as bloot 'n rigsnoer vir 'n regskape lewe totdat alles beëindig word deur die finale einde nie. As oor die lewe anderkant die einde nagedink word, geskied dit aan die hand van die nou reeds bekende Barth uitspraak, ${ }^{1}$ maar ook in die oortuiging dat die eskatologie ' $n$ deel is van die dogmatiese loci, wat nie ligtelik verbygegaan moet word nie. Daarom word in hierdie artikel gepoog om 'n bydrae te lewer tot die eskatologiese debat, en word gelyktydig die standpunt ingeneem dat dié besondere uitspraak in die Efesiërbrief daarvoor uitnemend geskik is. Die keuse vir die uitspraak word verskerp deur die toevoeging om reeds saam te sit in die hemel, wat instrumenteel is vir die keuse van die uitspraak as eskatologiese hoogbloei. Ander uitsprake in die brief kan ook eskatologies geïnterpreteer word, soos deur vakgenote aangedui word (Ef 1:3-14; 1:20, 21; 6:10-13, vgl. Zhekov 2005).

Ter aanvang word beklemtoon dat die Brief aan die Efesiërs as ' $n$ deutero-Pauliniese brief beskou word en as sodanig hanteer word (vgl. Van Wyk 2016).

\section{Enkele historiese verwysings na eskatologie aan die hand van bepaalde woordvoerders}

Eskatologie, nadenke oor die eskatologiese toekoms en wat daarmee saamhang in sy wydste verband, kan teruggevoer word tot die apostoliese vaders, waarmee 'n groep Griekssprekende skrywers van die eerste helfte van die tweede eeu aangedui word. Name soos Clemens van Rome, Ignatius van Antiochië, Polycarpus en Barnabas kan genoem word, asook die geskrif bekend as die Didache, die onderwysing van die twaalf apostels (Van Duijn 1999:148). Eskatologie ontstaan uit die aard van die saak in menslike denke en die ervaring dat 'n mens se lewe in die dood eindig, maar eindig alles met die dood? In die Christendom word die einde ' $n$ dominante tema in die teologiese debat wat nou verwant is aan die godsbegrip wat in sodanige denke ter sprake kom. 'Gott wird erfahren als der heilige, unbedingt sittliche Wille, der auf die ganze Welt gerichtet ist, handelnd und fordernd, und an ihr sich durchsetzen will' (Althaus 1949:7, 9). Daarmee saam het die eskatologiese debat gependel tussen die spanning wat deur die huidige en die komende tydvakke verwoord word.

1.'Christentum, das nicht ganz und gar und restlos Eschatologie ist, hat mit Christus ganz und gar und restlos nichts zu tun' (Barth 1989:325). 
Eskatologie het in mindere of meerdere mate deel uitgemaak van die teologiese debat wat aanduibaar is in die Middeleeue, die Reformasie, asook die tydperk ná die Reformatoriese tyd. Eskatologie word ook gevind in bepaalde teologiese strominge, soos die radikale in die sestiende eeu (vgl. Balke 1999:243), die Nadere Reformasie, Piëtisme, Puritanisme, en ook in die sogenaamde Verligting (vgl. Van 't Spijker 1999:210-242). ${ }^{2}$

Tydens die oorgang na die twintigste eeu was die Christelike toekomsverwagting ietwat oorwoeker deur die indrukwekkende prestasies op wetenskaplike en tegniese gebied van die negentiende eeu. Die oortuiging het bestaan dat alle gevare die hoof gebied sal kan word in 'n steeds beter-wordende wêreld. Ten spyte van 'n vooruitgangsgeloof met ' $n$ gepaste teologiese toonaard in Amerika, was daar in Europa, Oostenryk, Duitsland en Frankryk tekens van 'n kulturele pessimisme. Die twee wêreldoorloë wat in Europa sou volg (1914-1919, 1939-1945) het die aangeleentheid sterk op die voorgrond gedwing (Bosch 2005:502). 'Kortom - de omgang met de dood is een spiegel voor hoe de cultuur wanhopig zoekt naar toekomst - en hoe daarbij vertwijfeling en wanhoop elkaar daarbij afwisselen' (Den Hertog 1999:396).

Eskatologie is nie as die teologiese stiefkind behandel nie, maar tog geïnhibeer deur wat genoem word 'n hoop wat nie geskoei is op die koms en werk van Christus nie, maar eerder 'n hoop gegrond op die ontwikkeling en vooruitgang van menslike vermoëns en wat sou uitloop op 'n samelewing van vrye, sedelik-bewuste en verantwoordelike mense wat die samelewing soos 'n suurdeeg sou deursuur. Hiervoor was die lesings van A. von Harnack (1851-1930), Das Wesen des Christentums aan die Berlynse Universiteit gedurende 1899-1900, 'n sprekende voorbeeld (Den Hertog 1999:397; vgl. Naude 1983:15).

Die eintlike stimulus tot die herontdekking van die eskatologie het uit die geledere van die Nuwe Testamentiese wetenskap gekom, soos Johannes Weiss (1863-1914) wat aan eskatologie die betekenis heg van die 'radicaal-transendente Koninkrijk, dat het heden onder druk plaatst' (Den Hertog 1999:401; vgl. Naude 1983:79). Die naam van Albert Schweitzer (1875-1965) kan ook genoem en onthou word vir wat bekend staan as sy konsekwente eskatologie, wat volledig beheers word deur die geloof in 'n spoedige koms van die Koninkryk van God wat dus deur die uitbly van die wederkoms geneutraliseer word. Moltmann (2004) is krities teenoor Schweitzer se eskatologie, wat hy 'consistent eschatology' noem, en stel:

Their error was to transpose eschatology into time, instead of seeing in eschatology a transformation of time itself. But true eschatology is not about future history; it is about the future of history. (pp. 259-266)

Schweitzer se konsekwente eskatologie kan eintlik as 'n afskeid aan die eskatologie beskou word (Den Hertog
1999:403; vgl. Naude 1983:178-182). Käsemann was ook krities teenoor beide Weis en Schweitzer in die mening dat hulle onseker was wat om met die nuutontdekking te doen (Bosch 2005:501)

Die kritieke vraag was, en is steeds, of die samelewing - in 'n poging om antwoorde op alle vrae te vind - uit eie kennis en ervaring put óf, daarteenoor, erns maak met die Bybels, Nuwe Testamentiese spreke oor die eskatologie wat normgewend beskou en bely word. Aan die einde van die Tweede Wêreldoorlog verskyn O. Spengler (1880-1936) se bekende werk, Der Untergang des Abendlandes (1929), wat die ondergangsstemming in Duitsland versterk het. Al het die werk die einde van die kulture in gedagte gehad, was daarin tog geen sprake van wat die Bybel onder die einde van die tyd verstaan nie. 'Zijn toekomstverwachting is deterministisch: de West-Europese cultuur loopt onherroepelijk op een einde, en zal plaatsmaken voor een technocratie' (Den Hertog 1999:409; vgl. Van Niekerk 2017).

Wiedenmann $(1965: 26,31,39,44)$ onderskei vier beduidende eskatologiese strominge in die Duitse Protestantisme, naamlik Barth se dialektiese eskatologie, die eksistensiële eskatologie van Bultmann, die aktuele eskatologie van Althaus, en die heils-historiese eskatologie van Cullmann.

Vir Barth (1886-1968) is die eskatologie nie konsekwent eskatologies nie, maar konsekwent Christologies, want die Nuwe Testamentiese eskatologie veronderstel konsekwent die feit dat die Ryk van God gekom het in die kruisiging en opstanding van Christus (Barth 1959:583). Die mening dat Barth se teologie in die algemeen en sy eskatologie in besonder as 'n uitstaande hoogtepunt in die twintigste eeu beskou kan word, verdien vermelding (vgl. Moltmann1964:28). Sy eskatologie is nóg eensydig individualisties, nóg universeel van aard. Daarnaas is sy eskatologie ook nie eensydig op die toekoms betrek nie, aangesien die ewigheid deur die opstanding van Jesus aangebreek het. Die ewigheid het met die opstanding van Jesus Christus in die hede aangebreek, en Jesus is in en deur die Heilige Gees nou reeds teenwoordig (Naude 1983:287-290).

Bosch (2005:502) beskryf die eskatologie van Barth as 'n hermeneutiese uitgangspunt: '[F]or what is ultimate and transcendent, an expression with which to repel even the slightest hint at human collaboration in bringing in the end'.

Bultmann sien eskatologie as die gebeure wat ontvou tussen die verkondigde Woord en die individu: 'Der Grundbegriff der Eschatologie und überhaubt der Theologie Bultmanns ist also die mensliche Existenz, die sich jeden Augenblick von Entscheidung zu Entscheidung selbst verwirklicht' (Wiedenmann 1965:31).

Die naam van Dodd (1884-1973) kan ook in dié verband genoem word omdat hy veral bekend geword het vir sy, wat genoem word, gerealiseerde eskatologie (Naude 1983):

Vir hom het die koninkryk van God met die koms van Jesus gerealiseer, maar die volheid van die koninkryk van God lê vir die individu ná sy sterwe in die transendente wêreld van God. (p. 227) 
Sy gerealiseerde eskatologie is presenties-individualisties van aard en verwys na die teenwoordigheid van die koninkryk van God tydens die aardse teenwoordigheid van Christus (Naude 1983:230): 'This world has become the scene of a divine drama, in which the eternal issues are laid bare. It is the hour of decision. It is realized eschatology'. Gelowiges word onder appèl geplaas om hulle te bekeer en die evangelie te glo, want die Koninkryk van God is op hande (vgl. Mark 1:15):

It assumes that history in the individual life is of the same stuff as history at large; that is, it is significant in so far as it proves to bring men face to face with His Kingdom, power and glory. (Dodd 1971:148, 152)

Jeremias wys daarop dat die gelykenisse van Jesus in gemeen het dat hoorders opgeroep word om tot ' $n$ beslissing te kom oor Jesus (Jeremias 1972):

For they are all full of 'the secret of the Kingdom of God' (Mark $4: 11)$, that is to say, the recognition of 'an eschatology that is in process of realization'. (p. 230)

Jeremias dui in 'n voetnota aan dat die Duitse vorm, naamlik 'sich realiserende Eschatologie', deur Ernst Haenchen genoem is en dat Dodd daarmee saamgestem het (Jeremias 1972:230). Dit het beteken dat tyd en geskiedenis weer ' $n$ groter rol in Dodd se siening gespeel het, soos blyk uit die adventsoordenkinge wat oor die BBC uitgesaai is (1950), waarin 'n sterker toekomsperspektief by Dodd na vore kom (Van der Merwe 1981:82).

Die aktuele eskatologie van Althaus vertoon trekke van Dodd se siening, behalwe dat Althaus waarskynlik sou verkies het om te praat van eskatologie wat in die proses is om te gebeur. Gesien in die lig van die feit dat die einde van die wêreld in die oordeel deur die Koninkryk van God in Christus gebeur, staan elke oomblik asook die geskiedenis as geheel in die teken van die einde. Die parousia is nie toekomstige gebeure nie, maar eerder die opheffing van alle geskiedenis: 'Therefore it is immaterial whether the end is "chronologically" close or distant - it is essentially always near' (Bosch 2005:503).

Die eskatologie van die jonger Barth, Bultmann en Althaus word krities beoordeel in die sin dat al drie ahistories is en gelowiges gevolglik hulpeloos laat om die uitdagings van die huidige bestel die hoof te bied, en wat ook in gebreke bly om gelowiges daarvan te verseker dat God nie net toekomstig eskatologies is nie, maar nou reeds regeer. Gelowiges leef tussen die tye, tussen Jesus se eerste en tweede koms, dit is die tyd van die Gees wat nie 'n aanduiding is van God se afwesigheid nie (Bosch 2005:503).

Die mening van Küng (1978:198-199) is van belang. Hy wys daarop dat eskatologie nóg toekomstig (konsekwent eskatologies, volgens Schweitzer) - wat die hede negeer nóg slegs teenwoordig (soos in die gerealiseerde eskatologie van Dodd beklemtoon word) is: 'Uitspraken over de toekomst en over het heden, die beide in de evangeliën te vinden zijn, dienen serieus te worden genomen en gedifferentieerd op elkaar te worden betrokken'. Hede en toekoms staan in 'n wesenlik onoplosbare spanning. Daar kan nie sprake wees van die toekomstige ryk van God sonder om die implikasies daarvan vir die hede in ag te neem nie.

Die mening van Crossan (1999) is dalk redelik bruikbaar as klem op die belang van eskatologie as sodanig, waardeur ook beklemtoon word wat Küng reeds gestel het, naamlik dat eskatologie omvattend is en nie net huidig of toekomstig is nie:

The only way I can resolve that confusion is to take eschatology as a genus-level term and place future, apocalyptic, present, realized, or any other type of eschatology as a species-level distinction under that umbrella ... Taking eschatology as a genus or upper-level term accords, actually, with scholarly practice in using phrases such as realized eschatology, thorough-going eschatology, imminent eschatology, present eschatology, future eschatology, and even (sometimes but not consistently) apocalyptic eschatology. (pp. 258-259)

Dié mening boekstaaf dat die siening van Crossan bruikbaar geag word vir 'n huidige eskatologie wat, soos Barth aangedui het, Christosentries gegrond is en die totaliteit van menslik, gelowige bestaan insluit - dié mening in die lig van die Pauliniese uitspraak dat iemand wat in Christus is ' $n$ nuwe skepsel is (2 Kor 5:17) (Runia 1999:443).

In die voorafgaande paragrawe oor bepaalde woordvoerders van eskatologie uit die verlede, is dit duidelik dat daar nie net na navorsers uit een teologiese dissipline verwys word nie. Ook Bybelwetenskaplikes word geraadpleeg, veral met betrekking tot die Nuwe Testament. Daarnaas is ook na dogmatici verwys, soos Barth en Moltmann, wat' $n$ besondere bydrae gelewer het tot die onderwerp ter sprake. Die noue verband tussen die Nuwe Testamentiese wetenskap en die Dogmatiek is opvallend aangesien die Dogmatiek tot 'n formulering kom ná grondige bestudering van die Skrif en wat daarmee saamhang. As Dogmatiek dan veral as kerklike dogmatiek gesien word (vgl. Barth 1964:16), is die verband nóg nouer, aangesien kerklike handelinge 'n Skriftuurlike onderbou het wat geldend is, ook vir alle teologiese dissiplines. Dit verbaas dus nie dat eskatologie ook sterk missionaal gebind is nie. Tot dié slotsom kom iemand soos Bosch ná sy breedvoerige bestudering van 'n Skriftuurlike fundering van missionaat en derhalwe dus ook 'n noue verbinding tussen eskatologie en missionaat (vgl. Bosch 2005:15-178). Eskatologie kan as die dryfveer gesien word waarom die klem op missionaat geplaas word as 'n omvattende singewing tot missionale arbeid hier en nou, wat in die onderhewige uitspraak in die Efesiërbrief besondere aandag ontvang as 'n toekomsverwagting reeds in die huidige konteks. Dit moet veral gesien word in die lig van die feit dat missionaal nie ' $n$ onderafdeling van kerklike arbeid is nie, maar eintlik die kerk se wese en gang as geheel verwoord.

\section{Eskatologiese trekke in die brief aan die Efesiërs, met besondere verwysing na Efesiërs 2:6}

'Ja, Hy het ons in Christus Jesus saam opgewek en saam laat

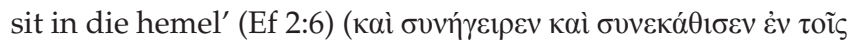

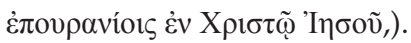


Dié uitspraak kom in die eerste tien verse van hoofstuk twee voor, waaroor MacDonald (2008:234) sê dat die gedeelte as 'n samestelling van tradisionele elemente beskou kan word, soos Joodse apokaliptiese motiewe (Ef 2:5-7), antieke kosmologie (Ef 2:2) en Joodse uitinge van nie-Joodse sondigheid (Ef 2:2-3). Lincoln (1990:35, 41), in sy bespreking van Efesiërs 1:10, wys daarop dat daarin reeds ' $n$ voorbeeld gevind word van 'n gerealiseerde eskatologie in die Efesiërbrief. Dit hang saam met die gedagtegang van die brief dat alles in die hemel en op die aarde onder een Hoof saamgebring sal word. Daar is spanning tussen wat reeds gebeur het en wat nog sal gebeur (vgl. MacDonald 2008:236). In verband met God se heerskappy oor die magte (Ef 1:21, 2:2,6:12) en in die lofprysing is die perspektief 'n gerealiseerde eskatologie waar die omvattende voltooiing van God se doel geantisipeer word. Lincoln verwys ook na Efesiërs 1:12, waar die werkwoord $\pi \rho \circ \varepsilon \lambda \pi i \zeta \omega$ gebruik word as 'n hapax legomenon in die Nuwe Testament wat hy as betekenisvol vir die eskatologiese perspektief van Efesiërs beskou. Deur die gebruik van die leenwoord $\alpha \rho \rho \alpha \beta \omega ́ v$ (Ef 1:14) uit Hebreeus (Gen 38:17-20), word op die eskatologiese spanning in die Efesiërbrief gedui. Die gerealiseerde eskatologie word ook aan die toekoms gebind deur die uitspraak in Efesiërs 1:21, naamlik: '... nie alleen in hierdie bedeling nie, maar ook in

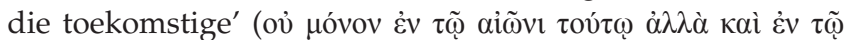
$\left.\mu \varepsilon ́ \lambda \lambda \mathrm{ov \tau l}^{\circ}\right)$, waardeur beklemtoon word dat eskatologie nie net betrekking het op die toekoms, hede of verlede nie, maar eerder alles insluit (Lincoln 1990:65-66).

Met verwysing na die dood van Christus as 'n keerpunt in die menslike bestaan, kan aanvaar word dat Christus se opstanding 'n aanduiding vorm van lewe wat in die vooruitsig gestel word. Wie daarvan uitgesluit is, bevind homself in 'n doodsbestaan. Ten spyte van die fisiese dood wat elke gelowige (Rom 6:23) gedeeltelik in hierdie lewe ervaar, is daarin tegelyk 'n voorbeeld van gerealiseerde eskatologie, wat raar genoeg deur die fisiese dood vergestalt word:

The realized eschatological view of death in Col 2:13 and Eph 2:1 as a natural continuation of such thinking, as the past is contrasted with the present experience of resurrection life. (Lincoln 1990:93)

Deur die gebruik van die aoristus ('saam lewend gemaak')

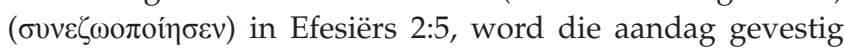
op die voortgaande gevolge van die redding vir die hede, en strook dit met dieselfde werkwoordvorme in vers 6 as aanduiding van ' $\mathrm{n}$ gerealiseerde eskatologie (Lincoln 1990:105).

In verband met Efesiërs se gerealiseerde eskatologie, val die aandag veral op Efesiërs 2:6, ('... ons in Christus Jesus saam

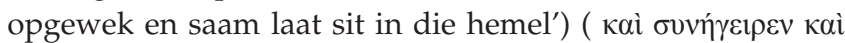

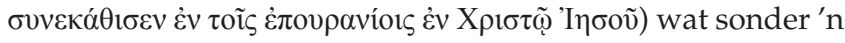
datief weergegee word, maar deur die $\tau \tilde{\omega}$ X $\rho\llcorner\sigma \tau \tilde{\omega}$ van vers 5 versterk word, en ook aangevul word deur $\dot{\varepsilon} v$ X as aanduiding van hoe die saam opwek en saam laat sit in die hemel moontlik is en dikwels in die brief aangewend word (MacDonald 2008:232). Thielman (2013:3887) meen die opvallende van die drie werkwoorde wat met ovv- begin, setel in die feit dat al drie in die verlede tyd geformuleer is as aanduiding dat dit reeds gebeur het, waarvan die stelling dat gelowiges nie net opgewek is nie, maar reeds saam in die hemel is, besondere aandag trek.

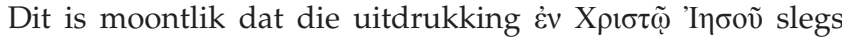
beteken dat dit deur Christus moontlik is, maar Lincoln is van mening dat die sterker betekenis van 'having been incorporated into Christ' hier gepas is. Die betekenis is ' $\mathrm{n}$ aanduiding dat dit wat met Christus gebeur het, ook met gelowiges gebeur. Gelowiges is dus in Christus ingesluit as die verteenwoordiger van 'n nuwe mensheid. Die klem op 'saam' ( $\sigma 0 v-)$ in die twee bogenoemde werkwoorde in vers 6 veronderstel ' $n$ verhouding van solidariteit en intimiteit tussen Christus en gelowiges:

The statement that God has both raised up believers with Christ and seated them with him in the heavenly realms spells out the implications of the relationship of incorporation in Christ in their most developed form in the Pauline corpus. (Lincoln 1990:105, [author's own italics])

Arnold (2016:3522-3548) argumenteer dat gelowiges lewend gemaak is deur 'n dinamiese eenheid met Christus, waardeur hulle in staat gestel word om in die voordeel daarvan te deel. Volgens Arnold pas die skrywer toe wat reeds (Ef 1:20 en Kol 2:12, 3:1) gesê is. Deelname aan die opstanding van Christus word verrassend aangepas en verleng tot 'n deelname wat ook as 'sit in die hemel' moontlik word. Beide uitsprake skep spanning met die tipies Pauliniese uitsprake dat opstanding en hemelvaart vir die toekoms gereserveer is (vgl. 1 Kor 4:8; 2 Tim 2:18). Wanneer daar sprake is van die deelname aan die opstanding van Christus (Rom 6), gaan dit nie oor die opstanding van die eie liggaam nie. Dit is vir die toekoms gereserveer, maar is 'n deelname aan die opstanding van Christus met gevolge vir die hede.

Dit word beklemtoon deur die in Christus en die saam belewenis wat in die twee betrokke werkwoorde geformuleer is, as ' $n$ aanduiding van die aard van die opstanding en verhoging. Die draagkrag van die deelname tot selfs in die hemel nou reeds, kan gevind word in Efesiërs 1:20-23, waarin beklemtoon word dat sy heerskappy oor alles kosmologies is, waaraan alle magte en kragte onderwerp is. In die eerste hoofstuk word die verhouding tot die Triniteit beklemtoon, terwyl in hoofstuk 2 aangedui word hoe dit gelowiges raak tot in só ' $n$ mate dat gelowiges reeds in die hemel is (Hoehner 2013:6542). Dit is wat die skrywer wou meedeel: 'By virtue of their union with Christ, they now share in his power and authority over the principalities, powers, authorities, and, indeed, any spiritual power they can think of'. Dit was van besondere troos vir gelowiges wat bose magte gevrees het (vgl. Kol 2:8). Daarom is die noue verbintenis aan Christus, wat hoër en groter en kragtiger is as enige bose mag, van besondere troos. Hoehner (2013:7109) sluit hierby aan met sy mening dat 'the position of being seated with Christ in the heavenlies gives the believer a heavenly power to overcome the power of sin and death'. Die verhouding tussen Christus en gelowiges verleen toegang tot ' $n$ bestaan wat in die hemel is ten spyte van die aardse bestaan. 
Die idee om opgewek te wees in Christus is nie uniek nie, maar kom ook voor in Kolossense 2:12 en 3:1 (wel in die passiewe werkwoordvorm), terwyl Efesiërs aandui dat God gelowiges opgewek het in Christus, soos geformuleer in Efesiërs 1:20 waar soortgelyke begrippe voorkom (MacDonald 2008:232). Die feit dat die Efesiërbrief dit anders formuleer, word geïnterpreteer dat daar afgewyk word van die tipies Pauliniese siening soos in Romeine 6:1-11 gevind word. Romeine 6 stel twee vorme van denke, naamlik dat dit vir die gelowige in Christus moontlik geword het, maar dat die voltooiing daarvan nog in die toekoms lê. Paulus beklemtoon ook daar dat in Christus gesterf word in reaksie op die sonde (Rom 6:7). Soos Christus uit die dood opgewek is, só sal ook sondaars daaruit opgewek word. In Kolossense 3:3-4 word die toekoms beklemtoon wat nou nog verborge is, terwyl Efesiërs aandui dat dit gebeur het as voorbeeld van 'n gerealiseerde eskatologie. Alhoewel Efesiërs 1:20 nou aansluit by $2: 6$, is daar ook 'n belangrike verskil in die sin

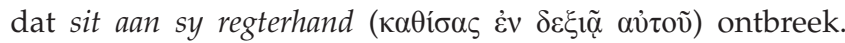
'Although believers share in Christ's exaltation, his position in the heavenly realm and his relationship to God are unique' (Lincoln 1990:106-107; vgl. MacDonald 2008:232).

Die uitspraak om reeds in die hemel te sit, is waarskynlik beïnvloed vanuit Kolossense, en ook vanuit die Gnostiek, maar kom meer voor in apokaliptiese literatuur, asook in die Nuwe Testament self, met verwysing na Matteus 19:28 en 1 Korintiërs 6:2. Die verwysing word ook in die selfverstaan van die Qumran gemeenskap gevind (vgl. Lincoln 1990:107; MacDonald 2008:234; Talbert 2007:62). Wanneer die gemeente van Kolossense onder druk verkeer en daar verwys word na misleidende filosofieë en aanbidding van engele, antwoord die skrywer deur wat genoem kan word 'n gelowige genoegdoening en afgrensing teen die onbruikbare in die lig van wat in Christus reeds voor hande is en as 'n gerealiseerde eskatologie tipeer kan word. Efesiërs sit die argument voort met die klem dat dit in Christus gebeur het en seker is, omdat gelowiges in Christus daaraan deel kry. Behalwe die Kolossense agtergrond, word daar ook in ander Pauliniese teksgedeeltes spore gevind van ' $n$ teenswoordige belewenis van die hemel (vgl. Gal 4:26; 1 Kor 15:47-49; 2 Kor 12:2-4; Fil 3:20).

Wanneer Paulus hierdie beeld gebruik (Rom 6), het hy nie een of ander religieuse ervaring in gedagte nie, maar '[he] rather thought of believers as having been Christ's partners in the events of past redemptive history' (Lincoln 1990:108). Christus se dood hoort by die ou orde waar sonde heerskappy gevoer het, terwyl Christus se opstanding 'n nuwe bedeling ingelei het waarin Hy regeer as God, as Hoof van die kosmos en daarom ook van die kerk (Ef 1:22). Gelowiges deel daarin en al is dit nog voorlopig, is dit tog dialekties en daarom eskatologies gerealiseerd; 'n opwindende toekoms wat reeds gebeur het. Wanneer die skrywer sê dat die lesers dood was maar deur Christus opgewek is, dui hy aan dat die Christusgebeure ook op gelowiges van toepassing is - so asof alles reeds voltooi is.

Lincoln (1990:91; vgl. Hoehner 2013:7127) sê dat hoewel daar geen eksplisiete verwysing na die doop in Efesiërs 2:1-10 voorkom nie, daar ook geen rede is om te argumenteer dat die lesers as gevolg van hulle omwenteling van hoe dit vóór Christus was en hoe dit ná Christus daar uitsien, as gevolg van genade en hulle deelname aan wat met Christus gebeur het, hoegenaamd nie die betekenis van hulle doop in herinnering sou roep nie. Die vermoede bestaan dus dat lesers hierdie totale omwenteling waardeur hulle nie net opgewek is nie, maar spreekwoordelik en eskatologies reeds in die hemel is, deur hulle doop ervaar het (Lincoln 1990:109). MacDonald (2008:235) stel dit nog sterker met die mening: '[I]t is almost beyond question that the recipients would have recalled their baptism as they heard 2:1 and 2:5-6 proclaimed in the midst of the ekklessia'. Behalwe die doop-moontlikheid, voeg MacDonald (2008:232) die volgende in verband met vers ses by: 'This verse has many points in common with Col 3:1-4, but the perspective of "realized eschatology" stands out even more sharply in Ephesians'.

In verband met die egte Pauliniese literatuur, argumenteer Thielman (2013) dat Efesiërs en die briewe wat as eg Paulinies aanvaar word slegs in balans verskil:

Ephesians clearly emphasizes the realized aspect of the tension. Nevertheless, what we find in Ephesians does not stand in contradiction to the theology of the undisputed letters but places emphasis on one side of the typical Pauline eschatology because of the situation that the letter addresses. (p. 3959)

In die lig van 'n gerealiseerde eskatologie, is die mening van Hoehner (2013) van belang:

On the one hand, we have a realized eschatology but, on the other hand, we wait for this eschatology to be fully realized. This corporate solidarity is a reality now but in the future its reality will be enlarged as we fully bond with our Saviour, with new bodies and without sin. (p. 7136)

$\mathrm{Na}$ aanleiding van die onderhewige teks, meen Talbert (2007:73-74) dat die Efesiërbrief 'n toekomstige hoop én 'n gerealiseerde (inaugurated) eskatologie verwoord. Dit was en is steeds ' $n$ besondere vertroosting om te hoor dat gelowiges reeds in die hemel sit, waardeur aangedui word dat gelowiges ver bokant elke owerheid, gesag, mag en heerser (Ef 1:21) verhef is en sodoende eintlik oor hulle heerskappy voer. Dit hou die belofte in dat gelowiges oor sonde en vyandige geestelike magte heerskappy kan voer; nader gesien: moét voer. Noudat gelowiges verseker word dat hulle spreekwoordelik reeds in die hemel sit in afhanklikheid van Christus, is dit moontlik om die boosheid koninklik te oorheers. Efesiërs leef onder die indruk dat daar bose geeste in die lug is (Ef 2:2; 6:12), wat die vraag na vore gebring het of Christus magtiger is as die gewaande bose geeste. Daarom fokus die brief op God se mag wat toeganklik is vir gelowiges, wat nou opgeroep word om die wapenrusting (Ef 6:10-20) aan te trek. Volgens Efesiërs was gelowiges dood, maar is opgewek - selfs daarby verby in die nuwe bestaan van saam sit in die hemel, bokant al die magte en kragte wat die lewe van gelowiges bedreig.

Talbert (2007:74-75) beskou Efesiërs se eskatologie temporeel, wat nie net in hierdie bedeling geld nie, maar ook in die 
toekomstige (Ef 1:21), wat die hoop is wat sy roeping inhou (Ef 1:14), waarborg van gelowiges se erfdeel (Ef 1:14), hoop van die roeping (Ef 4:4), verseël vir die dag van bevryding (Ef 4:30) en dat geen immorele persoon deel het aan die koninkryk van Christus en van God nie. Twee beelde versier die eskatologiese diepgang, naamlik gelowiges (die kerk) as tempel van die Here (Ef 2:19-22) en die menslike liggaam wat groei tot volwassenheid (Ef 4:11-16). Beide beelde is tiperend van die groei van die kerk tot en met die einde. Efesiërs behou die alreeds maar nog nie van die egte Paulusbriewe, maar beklemtoon die huidige ter wille van sy lesers. Efesiërs behou die temporele eskatologie van die egte briewe, maar beklemtoon die huidige deur gebruikmaking van ruimtelike metafore as aanduiding van die groei van gelowiges (die kerk) in die tyd voor die einde.

\section{Eskatologie in missionale konteks}

Tydens die Willingen-konferensie van die International Missionary Council (IMC) wat in 1952 plaasgevind het, is in meer algemene begrippe na die 'entrance of the eschatological foundation of mission into the ecumenical discussion' verwys (Bosch 2005:502). Soos reeds aangedui, was daar op dié tydstip vier onderskeibare eskatologiese rigtings ter sprake, verteenwoordig deur Barth, Bultmann, Althaus en Cullmann, wat elkeen ' $n$ bepaalde invloed uitgeoefen het op missionale denke. Bosch (2005:504) dui aan dat die genoemde eskatologiese rigtings in verband met die missionale debat tog 'offshoots of the salvation-history approach' was, selfs al sou dit ontken word (vgl. Flett 2010:150).

Cullmann (1967), in sy heils-historiese benadering van die eskatologie, is van mening dat:

... the root of all New Testament eschatology lies not in the expectation in and of itself that the end is imminent, but in the tension characteristic of the New Testament's salvation history, and that this is already present in Jesus. (p. 38)

Daar is egter nie twee verskillende geskiedenisse nie, maar twee maniere waarop geskiedenis verstaan kan word. 'n Gelowige mens sal die hand van God in die geskiedenis nie kan miskyk nie. Christelike eskatologie beweeg in die verlede, hede en toekoms. Die koninkryk van God het gekom, kom steeds en sal kom in sy volheid. 'n Missionale eskatologie is op die toekoms ingestel, maar beweeg in die hier en nou. Eskatologie hou die alreeds en nog nie in kreatiewe en verlossende spanning; die wêreld van sonde en opstand, is die wêreld wat God lief het. Die nuwe het reeds begin, maar die ou wêreld het nog nie geëindig nie (Bosch 2005:508). Bosch verwys na Freytag en Cullmann, wat beklemtoon dat eskatologie outentieke betekenis aan die missionale opdrag gee. Freytag (1961:222) reageer teen die katastrofiese gevolge van die Tweede Wêreldoorlog en lewer 'n pleidooi om af te sien van suksesdenke en om te doen wat gedoen moet word, ongeag die uitkoms daarvan. 'The validity of the views of Freytag and Cullmann lies in their unflagging insistence that there is no authentic mission without a fundamental eschatological disposition' (Bosch 2005:506).
Moltmann (1964:28) verwys na die bekende en reeds aangehaalde uitspraak van Barth, waarin hy stel dat die uitspraak van Barth 'als een programma' klink. Hy meen dat die omgekeerde waar is van wat Schweitzer beweer het, naamlik dat die geskiedenis die eskatologiese toekomsverwagting in 'n krisis geplaas het. Dit is eerder so dat die eschaton, wat op transendentale wyse aanbreek, die geskiedenis in sy laaste krisis verplaas. Daardeur word die eschaton self transendentale ewigheid, sin en betekenis van alle tye.

Daar is dus meriete in wat Agaard beweer (soos aangehaal deur Bosch 2005:507), dat sedert die sestigerjare van die vorige eeu daar in Europese missionêre kringe 'n sterker eskatologiese perspektief na vore gekom het. Die appèl ontstaan om ' $\mathrm{n}$ missionale teologie te formuleer in die lig van 'n outentieke eskatologie. Bosch is oortuig dat eskatologie bepalend is en die horison vorm vir alle Christelike begrip. Vir hom kan die klem nie net op eskatologie val nie omdat die krisisse van die wêreld sodoende misgekyk word. Eweneens kan ook nie net eensydig op die missionale uitdagings gefokus word met uitsluiting van die transendentale dimensie nie. Daardeur word gelowiges gestroop van begrip en die teleologiese word onderwaardeer, waarsonder niemand kan oorleef nie (Moltmann 1975:20-24).

Bosch (2005:508) stel dit duidelik: 'n missionale eskatologie wat op die toekoms gerig is, maar nie perspektief op die hede verloor nie, is bruikbaar. 'n Eskatologie wat die alreeds en nog nie in kreatiewe en verlossende spanning hou. 'n Wêreld van sonde en rebellie, maar wat God liefhet. Die nuwe bedeling wat reeds begin het, terwyl die ou bedeling nog nie geëindig het nie; geregtigheid en regverdiging. Christelike hoop spruit nie uit wanhoop in die huidige bestaan van gelowiges nie, maar hoop in wat reeds ervaar word, al is dit nog nie volledig nie. Eskatologie wat in Christus gedrewe is (vgl. Barth 1989:325), fokus nie net op die verlede nie, maar put uit die verlede met die oog op die toekoms tot singewing van die hede. Daarom het eskatologie alles met Christus te doen, want die evangelie van die gekruisigde en opgestane Heer is die enigste alternatief vir die bestaan bokant menslike begrip.

Dit is die rede waarom die uitspraak in Efesiërs 2:6 die oog vang, want dit spreek van eskatologiese diepgang vir mense wat aan die aardse bestel gebonde is, maar wat tog hoor dat die huidige reeds deur die toekomstige bestaan in die hemel bepaal word. Die kerk bly in gebreke om homself te verstaan indien die kerk die fundamentele verhouding tussen die Koninkryk van God en die wêreld miskyk. Anders gestel, eskatologie gaan vooraf aan ekklesiologie (Flett 2010:51).

Wiedenmann (1965) was oortuig daarvan, wat steeds geldig is, dat die dialektiese verstaan van eskatologie, soos verwoord deur Barth, Hartenstein en Kramer, in mindere of meerdere mate die grondpatroon gevorm het vir die eskatologiese verstaan van missiologie:

Nach der dialektischen Eschatologie besteht der eschatologische Charakter der Mission darin, dass Gott auch ,das Ende' der 
menschlichen Missionstätigkeit ist, d.h. dass er in ihr der eigentlich und allein Handelnde ist (vgl. Flett 2010:11-17). (bl. 191)

Margull (1959:30) wys daarop dat, veral na afloop van die Tweede Wêreldoorlog, die missiologiese debat ook gevoer is deur Nederlandse teoloë soos Van Ruler (1908-1970) en Ridderbos (1879-1960), naas Kraemer. Van Ruler (1948: 20-21) sien die kerk in volle eskatologiese lig en ruimte. Die apostolaat van die kerk is 'n eskatologiese funksie. Die kerk is apostolies wanneer dit deur God aangewend word om die eskatologiese bestemming van mens en wêreld te realiseer. Margull (1959) het in die sestiger jare reeds daarop gewys dat alleen:
... im eschatologischen Ergriffensein wird der neue Gehorsam möglich sein, den das Wort fordert, wenn es heute in die Welt will; nur im Glauben an das eschatologische Handeln Gottes mit seiner Kirche ist Erneuerung denkbar. (p. 92)

$\mathrm{Na}$ aanleiding van die eskatologiese klem wat in die missionale debat sedert die Tweede Wêreldoorlog na vore kom, is dit gepas om te stel dat eskatologie belangriker is as wat dalk normaalweg besef word. Missionale arbeid sonder 'n toekomsverwagting is waarskynlik diensbaar tot uitbreiding van die getalle van die kerk, maar gaan mank aan Bybelse diepgang. Daarom stel hierdie artikel dat opwekking deur Christus, gevolg deur saam sit in die hemel, 'n dimensie verleen wat anderkant menslike kreatiwiteit lê. Daarin setel die eskatologiese voorrang van die uitspraak, omdat vir gelowiges meegedeel word dat hulle reeds daar is, al is hulle tog nog hier, maar terselfdertyd tog verseker word dat die toekoms tot daar strek waar gelowiges nou nog nie is nie.

\section{Theosis ( $\theta \varepsilon \omega \sigma \iota \varsigma)$ en eskatologie}

Dit is redelik algemeen aanvaarbaar om te sê dat alle godsdienste poog om 'n antwoord te gee oor die verhouding tussen mens en die god wat in sodanige verband bely word. Enige godsdiens wat sy beloftes waar wil maak, kan dit alleen doen deur antwoord te gee op die mees voor die hand liggende vraag wat gestel word: 'What is the way back to God, to live with God, to live in God and share in the divine?'. Christelike teologie het uit die staanspoor aan sy volgelinge ' $n$ antwoord probeer gee deur middel van 'n leer van vergoddeliking en/of eenheid met God. Die soeke na eenheid met God is ongetwyfeld die leitmotif van godsdienste in breër verband (Kärkkäinen 2004:1, 2). Polkinghorne (1991:103) is van mening dat, in die debat tussen moderne wetenskap en teologie, die aanname van Ortodokse teoloë dat die werklike einde van die skepping in vergoddeliking (deification) of theosis geleë is, aandag verdien. Die aangeleentheid word teruggevoer tot Irenaeus se uitspraak oor vergoddeliking: 'God became human that we might become divine' (Peacocke 1993:189). Blackwell (2010) stel:

Irenaeus is often noted as the patristic writer who lays the foundation for deification in the eastern tradition, which leads some to apply liberally the term deification to the whole of Irenaeus' soteriology. (p. 30)
Kärkkäinen (2004:4) wys daarop dat theosis in die Oosterse en regverdiging in die Westerse teologiese debat een ding in gemeen het, naamlik eenwording met God as uiteindelike doel. Braaten (1983:63) se standpunt is dat soteriologie die geheel van die teologiese debat beheer en dat die Godsleer, Christus, kerk, sakramente en eskatologie vanuit die perspektief van die verlossingsleer bepaal word. Kärkkäinen (2004:96, 97) verbind theosis of vergoddeliking nou aan eskatologie omdat, na sy mening, laasgenoemde die volvoering is van die proses wat 'n Christen bokant sy natuur uitlig tot die bonatuurlike vlak van God. Hy vervolg verder met die argument dat daar ' $n$ groeiende konsensus is tussen die Oosterse siening van gelowiges se eenwording met God, soos verwoord deur theosis, en die Westerse siening van eenwording met God, soos aangedui deur die regverdigingsleer:

Theosis, both on an individual and cosmic scale, is not exiguous in its eschatological perspective, either. Theosis testifies to the inexplicably grand mystery of God's divine intimacy with human beings. (Kharlamov 2011:1)

Volgens die Oosters-ortodokse siening van theosis, kan die doel van persoonlike eenheid tussen skepsel en God gesien word as ' $n$ eskatologiese volvoering van bestaan in God wat sakramenteel voorafgegaan word in die Nagmaal. Eskatologie kom in die theosis debat sowel as in 'n persoonlike en kosmiese verband sterk na vore. Dit dui op die misterie van God se intimiteit met mense (Kharlamov 2011):

The process of the reconciliation and glorification that was accomplished by Christ requires active human participation. It is a transformative experience that enables human beings to 'become not who Christ is but what he is'. (p. 5)

In dié sin is theosis sinoniem met verlossing en heiliging. Gorman (2015) dui aan dat:
... theosis - Spirit-enabled transformative participation in the life and character of God revealed in the crucified and resurrected Messiah Jesus - is the starting point of mission and is, in fact, its proper theological framework. (p. 3)

Theosis begin met die doop en verloop deur die lewe van gelowiges wat neerkom op 'n eskatologiese voltrekking van die proses wat Christene oor die menslike beperkinge lei tot die bo-menslike vlak van God (Kärkkäinen 2004:96).

Alhoewel Bonhoeffer (1966:289) nie dieselfde begrippe gebruik nie, was dit vir hom ook vanselfsprekend dat gelowiges nie kan stol in hulle bestaan wat nooit verander nie, maar hulle móét, deur Christus na te volg, soos Christus word. Dit is die uiteindelike bestemming van 'n dissipel, naamlik om soos Christus te word. Wie homself aan Christus oorgee, moet ' $n$ beelddraer van Christus word. Moltmann se mening dat eskatologie nie net te make het met die laaste uiteinde van alles nie, is bruikbaar. Dit dui op 'n verskraling van die eskatologie indien eskatologie net ter sprake gebring word aan die einde van die kerklik-teologiese besinning. Christelike eskatologie het nie te make met finale oplossings nie, maar met die skepping van nuwe dinge: 'Christian eschatology is the remembered hope of the raising of the crucified 
Christ, so it talks about beginning afresh in the deadly end' (Moltmann 2004:75). Dit herinner aan Bonhoeffer se laaste woorde aan 'n medegevangene, Payne Best, in die Flossenbürg konsentrasiekamp toe hy gesê het: '[D]it is die einde, maar vir my 'n nuwe begin' (Moltmann 2004:83). Indien eskatologie slegs vir die einde gereserveer word, kan dit netsowel gelaat word omdat eskatologie op dié manier redelik betekenisloos word vir die huidige, vir die lewe.

\section{Slotopmerkings}

Die standpunt wat in hierdie artikel ingeneem word, is dat Efesiërs 2:6 - naas ander uitsprake in die Efesiërbrief wat eskatologies geïnterpreteer kan word - 'n besondere plek in eskatologie inneem en as sodanig hanteer moet word. Soos verskillende woordvoerders uit die verlede met betrekking tot eskatologie en toepasbaar op bogenoemde uitspraak aangehaal is, kan opnuut met instemming na Crossan verwys word, wie van mening is dat eskatologie omvattend is en nie net huidig of toekomstig, konsekwent of gerealiseerd, is nie. Soos wat ekklesiologie bruikbaar getipeer word as Christologiese ekklesiologie (vgl. Van Wyk 2017), kan dié standpunt ook van toepassing gemaak word op die eskatologie. Dit sluit aan by die kosmologiese uitspraak oor Christus, wat ' $n$ besondere dimensie aan die brief verleen in verband met die kerkbegrip wat in die brief ter sprake kom (vgl. Efesiërs 1:22-23). Dit is 'n omvattende uitspraak wat verskil van die egte Paulusbriewe en wat daarop dui dat die hoofskap van Christus omvattend is, en wat nie net die handelinge van alle mense, ongeag, bepaal nie, maar ook van alle gelowiges, en derhalwe ook van die kerk.

Die bekende Barth uitspraak, ten spyte van kritiek, kan nie buite rekening gelaat word nie omdat omvattend Christologies daarin geargumenteer word, waaronder eskatologie ingesluit word. Christus het gelowiges uit hulle doodsbestaan, wat deur die sonde veroorsaak is, gered. Diegene wie se lewe deur die sonde beheers word, is eintlik dood. Maar nou is almal deur Christus nuutgemaak deur 'n omkeer van die dood na die lewe. Die opstanding van Christus uit die dood dien as parallel vir die bemoeienis van God deur Jesus Christus met mense sodat, soos wat Christus uit die dood opgewek is, só is hulle óók opgewek. Die eskatologiese diepgang van die uitspraak is dat gelowiges nie net opgewek en uit die dood verlos is nie, maar reeds saam sit in die hemel. Dit terwyl die lesers steeds in die wêreld, in dié immanente bedeling, verkeer. Wat ter sprake is, gaan nie oor wat Wright (2011:105) 'n eskatologiese dualiteit noem nie, naamlik die huidige tyd en die tyd wat nog moet kom nie; ook nie oor 'n ontologiese dualisme tussen die bose aarde en die volmaakte hemel nie.

Eskatologie, wat letterlik 'n studie van die laaste dinge beteken, verwys nie net na die dood, laaste oordeel, hemel en hel nie. Die oortuiging bestaan eerder dat die geskiedenis iewers heen op pad is, onder die hand van God, tot 'n nuwe wêreld van geregtigheid en hoop. Eskatologie is omvattend en opwindend, veral omdat in die Efesiër-uitspraak gestel word dat gelowiges hier en nou reeds veel meer beleef, en onder leiding van die Gees (vgl. Ef 1:14) eens die volheid sal geniet:

I remain convinced that the way forward is to rediscover a true eschatology, to rediscover a true mission rooted in anticipating that eschatology, and to rediscover forms of church which embody that anticipation. (Wright 2011:276)

Die kerk moet uit sy, soos Wright dit noem, skisofrenie ontsnap wat slegs daarin bestaan om siele te wen en goed te doen aan elkeen wat dit wil ontvang. Dit gaan oor meer as dit. In die lig van die 'saam laat sit in die hemel': oor véél meer as dit. Dit is ' $n$ unieke voorreg om aan gelowiges hier en nou te verkondig dat hulle reeds dáár is en dat die aanvegtinge van die tyd aan die verbygaan is. Daarom is die lesers van die Efesiërbrief opgeroep om die wapenrusting (Ef 6:10-17) aan te trek in diens van oorlewing. Die standpunt word ingeneem dat 'n Bybels-gegronde eskatologiese bewussyn stimulus gee vir opwindende kerklikheid, ongeag wat die sogenaamde tydsgees gelowiges wil laat glo. Die immanente word ver oorwoeker deur die transendente, deur die eskatologie waarin gelowiges hoor dat hulle reeds in die hemel is, die aardse bedeling ten spyt.

Theosis, soos belig vanuit die Oosters teologiese denke, sluit nou by eskatologie aan in die sin dat reeds hier rigtinggewend geleef word om al hoe meer só te leef sodat aan die einde die begin realiseer; dit in die lig van Skrifuitsprake soos 2 Korintiërs 3:18 en 2 Petrus 1:4. Eskatologie, Christelike eskatologie, omvat verlede, hede en toekoms. Wright (2011) stel die volgende mening, waarmee hierdie artikel volkome saamstem:

And the church that is renewed by the message of Jesus' resurrection must be the church that goes to work precisely in that space, time and matter, and claims it in advance as the place of God's kingdom, of Jesus' lordship, of the power of the Spirit. (p. 277)

\section{Erkenning \\ Mededingende belange}

Die outeur verklaar dat hy geen finansiële of persoonlike verbintenis het met enige party wat hom nadelig kon beïnvloed in die skryf van hierdie artikel nie.

\section{Outersbydrae}

B.J.v.W. was die enigeste outeur betrokke by die skryf van die artikel.

\section{Etiese oorwegings}

Hierdie artikel volg alle etiese standaarde vir navorsing sonder direkte kontak met mens of dier.

\section{Befondsing}

Hierdie navorsing het geen spesifieke toekenning ontvang van enige befondsingsagentskap in die openbare, kommersiële of nie-winsgewende sektore. 


\section{Data beskikbaarheidsverklaring}

Data-deling is nie van toepassing op hierdie artikel nie, aangesien geen nuwe data in hierdie studie geskep of ontleed is nie.

\section{Vrywaring}

Die sienings en menings wat in hierdie artikel uitgedruk word, is dié van die outeur (s) en weerspieël nie noodwendig die amptelike beleid of posisie van enige geaffilieerde agentskap van die outeurs nie.

\section{Literatuurverwysings}

Althaus, P., 1949, Die letzten dinge, Bertelsmann, Gütersloh.

Arnold, C.E., 2016, Ephesians, Kindle edn., Zondervan, Grand Rapids, MI. (Zondervan Exegetical Commentary on The New Testament, 10).

Balke, W., 1999, 'De eschatologie van zestiende-eeuwse radicalen', in W. van't Spijker, W. Balke, L van Driel, K. Exalto \& W.H. Velema (red.), Eschatologie, pp. 243-258, De Groot Goudriaan, Kampen.

Barth, K., 1959, Die Kirchliche Dogmatik, III/2, Zollikon, Zürich.

Barth, K., 1964, Kirchliche Dogmatik, I/I, EVZ, Zürich.

Barth, K., 1989, Der Römerbrief, Theologischer Verlag, Zürich.

Blackwell, B.C., 2010, Christosis: Pauline soteriology in light of deification in Irenaeus and Cyril of Alexandria, E-Thesis, Durham University.

Bonhoeffer, D., 1966, Navolging, Ten Have, Amsterdam.

Bosch, D.J., 2005, Transforming mission, Orbis, New York. (Paradigm Shifts in Theology of Mission, American society of missiology series, 16).

Braaten, C.E., 1983, Principles of Lutheran theology, Fortress, Philadelphia.

Cullmann, O., 1967, Salvation history, SCM, London.

Crossan, J.D., 1999, The Birth of Christianity, Kindle edn., Harper Collins, SanFrancisco.

Den Hertog, G.C., 1999, 'Escatologische verwachting in een tijd van crisis', in W. van't Spijker, W. Balke, L van Driel, K. Exalto \& W.H. Velema (red.), Eschatologie, pp. 395-439, De Groot Goudriaan, Kampen.

Dodd, C.H., 1971, The parables of the kingdom, Collins, London.

Flett, J.G., 2010, The witness of god, the Trinity, Missio Dei, Karl Barth and the Nature of Christian Community, Eerdmans, Grand Rapids, MI.

Freytag, W., 1961, Reden und Aufsätze, vol. II, Kaiser, München.

Gorman, M.J., 2015, Becoming the gospel: Paul, participation, and mission, Kindle edn., Eerdmans, Grand Rapids, MI. (The Gospel and Our Culture Series).

Hoehner, H.W., 2013, Ephesians, Kindle edn., Baker, Grand Rapids, MI.
Jeremias, J., 1972, The parables of Jesus, SCM, London.

Kärkkäinen, V., 2004, One with God, Liturgical Press, Collegeville, Minnesota, MN

Kharlamov, V., 2011, Theosis: Deification in Christian theology, vol. 2, Kindle edn., Pickwick, Eugene.

Küng, H., 1978, Christen zijn, Gooi en Sticht, Hilversum.

Lincoln, A.T., 1990, Ephesians, Word Books, Dallas, TX.

MacDonald, M.Y., 2008, in D.J. Harrington (ed.), Colossians and Ephesians, Sacred Pagina Series, vol. 17: Ephesians, pp. 1-394, Liturgical Press, Collegeville, Minnesota, MN.

Margull, H.J., 1959, Theologie der missionarischen Verkündigung, Evangelisches, Verlagswerk, Stuttgart.

Moltmann, J., 1964, Theologie van de hoop, Ambo, Utrecht.

Moltmann, J., 1975, The experiment hope, SCM, London.

Moltmann, J., 2004, The coming of god: Christian eschatology, Kindle edn., Fortress, Minneapolis, MN.

Naude, J.P., 1983, 'n Kritiese evaluering van 'n aantal eskatologiese modelle van die twintigste eeu, DD-proefskrif, Universiteit van Pretoria.

Peacocke, A., 1993, Theology for a scientific age: Being and becoming - natural, divine, and human, Fortress, Minneapolis, MN.

Polkinghorne, J., 1991, Reason and reality: The relationship between science and theology, Trinity, Philadelphia, PA.

Runia, K., 1999, 'Tweede helft van de twintigste eeuw', in W. van 't Spijker, W. Balke, L van Driel, K. Exalto \& W.H. Velema (red.), Eschatologie, pp. 441-465, De Groot Goudriaan, Kampen.

Spengler, O., 1929, Der untergang des abendlandes, I Band I\&2, Beck'sche, München. Talbert, C.H., 2007, Ephesians and Colossians, Baker, Grand Rapids, MI.

Thielman, F., 2013, Ephesians, Kindle edn., Baker, Grand Rapids, MI. (Baker Exegetical Commentary on the New Testament)

Van der Merwe, H., 1981, Verwagting en voleinding, N G Kerkboekhandel, Pretoria.

Van Duijn, M., 1999, 'Eschatologie in de vroege kerk', in W. van't Spijker, W. Balke, L. van Driel, K. Exalto \& W.H. Velema (red.), Eschatologie, pp. 147-172, De Groot Goudriaan, Kampen.

Van Niekerk, A.A., 2017, Die dood en die sin van die lewe, Tafelberg, Kaapstad.

Van Ruler, A.A., 1948, Het apostolaat der kerk en het ontwerp-kerkorde, Callenbach, Nijkerk.

Van 't Spijker, W., 1999, 'Eschatologie bij de reformatoren', in W. van't Spijker, W. Balke, L van Driel, K. Exalto \& W.H. Velema (red.), Eschatologie, pp. 201-242, De Groot Goudriaan, Kampen.

Van Wyk, B.J., 2016, 'Jesus Christus as kefalē en die Gees as arrabōn vir die ekklēsia: 'n Eksegeties-hermeneutiese studie', Ph-D proefskrif, Potchefstroomkampus van die Noordwes-Universiteit.

Van Wyk, B.J., 2017, 'Efesiërs 1:14 en 1:22, 23 as 'n skriftuurlike maksimum minimum vir die ekklesiologie', HTS Teologiese Studies/Theological Studies 73(1), a4073. https://doi.org/10.4102/hts.v73i1.4073.

Wiedenmann, L., 1965, Mission und Eschatologie, Bonifacius, Paderborn.

Wright, N.T., 2011, Surprised by Hope, Kindle edn., SPCK, London.

Zhekov, Y.K., 2005, Eschatology of Ephesians, Evangelical Theological Seminary, Osijek. 